\title{
Biochemical Manifestations of Oxygen Toxicity in the Newborn Lamb
}

\author{
THOMAS N. HANSEN, CHARLES V. SMITH, ALFRED L. GEST, HARILYN W. SMITH, AND \\ MARK GIESLER \\ Section of Neonatology, Department of Pediatrics, Baylor College of Medicine, Houston, Texas 77030
}

\begin{abstract}
The purpose of this project was to study the role of lipid peroxidation in oxygen-induced lung injury in the newborn lamb. It was our hypothesis that injury to the microvascular bed of the lung by oxygen would coincide with a burst of peroxidative activity and would be accompanied by an increased rate of excretion of ethane and pentane in expired gas. We measured vascular pressures, the rate of lung lymph flow and concentrations of ethane and pentane in exhaled gas in 10 newborn lambs that breathed $>95 \%$ oxygen continuously. Our marker for oxygen-induced lung injury was an increase in the permeability of the microvascular bed of the lung to protein (an increase in the rate of lung lymph flow accompanied by an increase in the protein concentration in lymph). Although all $\mathbf{1 0}$ lambs demonstrated an abrupt increase in microvascular permeability to protein within 48 to $96 \mathrm{~h}$ of exposure to $>95 \%$ oxygen, the rates of ethane and pentane excretion remained unchanged throughout the entire experimental period. Lung tissue concentrations of glutathione decreased by $40 \%$ in the oxygen-exposed lambs and the concentrations of glutathione disulfide increased $85 \%$ relative to airbreathing controls. Activities of glutathione reductase and superoxide dismutase were lower in the lungs of the oxygen-exposed lambs than in controls, whereas the activities of glutathione peroxidase and catalase were not changed. We conclude that, in the lamb, changes in the rates of excretion of ethane and pentane do not correlate with the timing of injury to the microvascular bed of the lung. (Pediatr Res 28: 613-617, 1990)
\end{abstract}

\section{Abbreviations}

GSH, glutathione; $\gamma$-glutamylcysteinylglycine GSSG, glutathione disulfide

$\mathrm{P}_{\mathrm{a}} \mathrm{CO}_{2}$, partial pressure of carbon dioxide in arterial blood $\mathrm{P}_{\mathrm{a}} \mathrm{O}_{2}$, partial pressure of oxygen in arterial blood SOD, superoxide dismutase

The use of elevated oxygen concentrations is essential in the management of the pulmonary insufficiency frequently encountered in premature infants. Unfortunately, because serious lung damage can be produced by exposure to hyperoxia, the use of this therapy is limited by the need to minimize these damaging effects (1). Attempts to investigate the mechanisms responsible for hyperoxic lung injury have used a number of animal models, including the newborn lamb (2). Unlike the newborn of some species (3), the newborn lamb does develop lung injury from

Received January 26, 1990; accepted August 8, 1990.

Correspondence: Thomas N. Hansen, M.D., Department of Pediatrics, Baylor College of Medicine, One Baylor Plaza, Houston, TX 77030.

Supported in part by NHLBI Pulmonary Faculty Training Grant HL 07159 and BRSG RR05425-22 P49 from the NIH. exposure to $>95 \% \mathrm{O}_{2}(2)$. An additional advantage of this model is the ability to monitor continuously or sequentially the changes in hemodynamics and lung fluid balance that occur during the onset and progression of hyperoxic lung injury (2). However, despite the extensive physiologic characterization of the effects of hyperoxia on the lamb and the numerous morphologic and pharmacologic studies of hyperoxic lung injury in this and other animal models, the chemical changes responsible for initiation and progression of oxygen-induced damage are not well understood.

It is reasonable to assume that alteration of biologic molecules by reactive oxygen species is critical to the initiation of injury, but specific information is needed on the nature and extent of these changes and the manner in which the specific alterations contribute to damage. Recently, an increase in lung tissue concentration of GSSG in lambs exposed to $>95 \% \mathrm{O}_{2}$ for $72 \mathrm{~h}$ was reported (4). This increase in lung GSSG content was accompanied by a $60 \%$ decrease in lung GSH concentrations, resulting in a marked decrease in tissue GSH/GSSG ratios. A similar change in oxygen-treated adult rats also has been reported (5). GSSG is a very useful marker of increased exposure of biologic systems to reactive oxygen species. In addition, GSH and GSHdependent antioxidant enzyme systems are critical to cellular survival during oxidant challenge (6-8). Interestingly, cells, particularly in vivo, appear to be remarkably resistant to lethal effects from shifts in thiol/disulfide status that are much larger than those observed in the hyperoxic lambs $(9,10)$. Therefore, other molecular mechanisms of the initiation of injury need to be investigated.

A number of approaches to the study of lipid peroxidation arising from hyperoxic exposure have been reported, but the assessment of lipid peroxidation in vivo is difficult because of the chemical complexity of the processes involved and the varied and often potent biologic effects of many of the products formed (11). Although the limitations of the data must be considered carefully, measurement of ethane and pentane in expired gases offers a number of advantages to the study of lipid peroxidation in the hyperoxic lamb. Ethane and pentane are not themselves lipid peroxides, but are formed through the $\beta$-scission decomposition of $\omega-3$ and $\omega-6$ fatty acid hydroperoxides. The expired hydrocarbons can be measured with great sensitivity and because they are collected noninvasively, repeated determinations can be obtained from an individual animal.

In our study, we report the measurement of expired ethane and pentane in lambs during $5 \mathrm{~d}$ of exposure to $>95 \%$ oxygen. In addition, we measured vascular pressures, the rate of lung lymph flow and its protein concentration, lung tissue GSH and GSSG content, and tissue activities of SOD, catalase, and glutathione peroxidase and glutathione reductase.

\section{MATERIALS AND METHODS}

Surgical preparation. Previous papers $(12,13)$ describe in detail how we surgically prepared the lambs for experiments. Briefly, 
we operated on each of the lambs twice, first when they were less than $7 \mathrm{~d}$ old, and again 7-14 d later. For both procedures, we anesthetized the lambs with halothane and nitrous oxide and used a piston-type respirator (model 607, Harvard Apparatus Co., Inc., Millis, MA) for mechanical ventilation. Before and after surgery, we kept the lambs with their mothers for feeding and warmth.

During the first operation, we inserted polyvinyl catheters into the left carotid artery and jugular vein through an incision in the neck and advanced the catheters until their tips were in the thoracic aorta and right atrium, respectively. Through a left thoracotomy, we placed polyvinyl catheters directly into the left atrium and main pulmonary artery.

In the second operation, a right thoracotomy, we resected the systemic contributions to the caudal mediastinal lymph node and inserted a polyvinyl catheter, impregnated with heparin (TDMAC Processing, Polyscience, Inc., Warrington, PA), into the efferent duct of that node. In addition, we placed a $3 \times 3 \mathrm{~cm}$ silicone balloon (Silastic, Dow Corning Corp., Midland, MI) in the pleural space for subsequent measurement of pleural pressure. For both operations, we gave the lambs meperidine $(1 \mathrm{mg} /$ $\mathrm{kg} \mathrm{s.c.)} \mathrm{before} \mathrm{awakening} \mathrm{them} \mathrm{from} \mathrm{anesthesia} \mathrm{and} \mathrm{then} \mathrm{every}$ 6 to $12 \mathrm{~h}$ for the first $48 \mathrm{~h}$ of recovery. We allowed the lambs at least $3 \mathrm{~d}$ to recover from surgery before starting experiments.

Experimental procedure. We studied the effects of hyperoxia on 10 lambs. Their average weight was $9.3 \pm 1.6 \mathrm{~kg}$ and average age when experiments began was $23 \pm 8 \mathrm{~d}$. For these experiments, we took the lambs from their mothers and placed them in a sealed wood and lucite box into which oxygen flowed at 6-8 L/ min, a rate sufficient to keep the $\mathrm{PO}_{2}$ in the inspired gas greater than $93 \mathrm{kPa}$. We used buckets of ice to keep the box from becoming too warm and soda lime to keep the $\mathrm{PCO}_{2}$ less than $0.5 \mathrm{kPa}$. While the lambs were in oxygen, we fed them commercial infant formula (Similac, Ross Laboratories, Columbus, $\mathrm{OH}$ ) that provided them with $150 \mathrm{~mL} / \mathrm{kg}$ and $100 \mathrm{kcal} / \mathrm{kg}$ daily.

On $\mathrm{d} 1$, we studied the lambs first during a $2-3 \mathrm{~h}$ steady state period as they breathed room air and then for a 3-4 $\mathrm{h}$ period as they breathed $>95 \%$ oxygen. For $\mathrm{d} 2-5$, we studied the lambs in the morning during 3- to 4-h steady state periods as they breathed $>95 \%$ oxygen. We measured vascular and pleural pressures, heart rate, respiratory rate, arterial $\mathrm{pH}, \mathrm{P}_{\mathrm{a}} \mathrm{O}_{2}$, and $\mathrm{P}_{\mathrm{a}} \mathrm{CO}_{2}$. We collected samples of lung lymph every $30 \mathrm{~min}$ during the 3 - to 4 -h steady state periods and measured their volumes to the nearest 0.01 $\mathrm{mL}$; we obtained samples of aortic blood every $60 \mathrm{~min}$. Finally, we collected timed samples of expired gas for measurement of ethane and pentane concentrations in seven of the lambs. We measured ethane and pentane concentrations only when the lambs were breathing $>95 \%$ oxygen and, therefore, collected our first sample on $\mathrm{d} 1$ after the lambs had been breathing $>95 \%$ oxygen for 3-4 h.

We measured pulmonary arterial, left atrial, and aortic pressures with Statham P23Db strain gauge manometers (Statham Instruments, Hato Rey, Puerto Rico), and pleural pressure with a Statham PM131TC differential pressure transducer. The zero reference for vascular pressures was the level of the left atrium; for measurement of pleural pressure, zero reference was atmospheric pressure. We recorded pressure tracings on a Grass 7D 8channel amplifier recorder (Grass Instruments, Quincy, MA) and obtained heart rate and respiratory rate from phasic recordings of aortic and pleural pressures. We measured arterial $\mathrm{pH}$ and the partial pressures of oxygen and carbon dioxide in arterial blood and inspired gas at $39.5^{\circ} \mathrm{C}$ using a Radiometer blood gas analyzer (Radiometer America, Inc., Westlake, $\mathrm{OH}$ ).

For the measurement of expired ethane and pentane, we sedated the lambs with chloral hydrate $(50-100 \mathrm{mg}$ p.o.) and intubated them with a cuffed endotracheal tube. We connected the tube to a one-way valve that allowed the lambs to inspire hydrocarbon-free oxygen and allowed us to collect all expired gas into mylar bags in a bag-in-box apparatus connected to a water-filled spirometer. The lambs all breathed hydrocarbon-free oxygen for at least $2 \mathrm{~h}$ before any measurements were made. The spirometer measured the volume of gas displaced in the box, hence the volume of gas collected in the mylar bag. After the gas collection, we extubated the lambs and returned them to the oxygen chamber.

Postmortem studies. When the lambs developed significant respiratory acidosis, we anesthetized them with sodium pentobarbital $(20 \mathrm{mg} / \mathrm{kg}$ i.v. $)$ and resected their lungs at an inflation pressure of $25 \mathrm{~cm} \mathrm{H}_{2} \mathrm{O}$. After resection, we perfused one lung with cold saline until it was free of blood, freeze clamped a segment with aluminum tongs cooled with liquid nitrogen, and stored the tissue at $-70^{\circ} \mathrm{C}$ before biochemical studies. We homogenized the other lung to measure extravascular water content by modification (14) of the method of Pearce et al. (15).

A group of six lambs of similar age and weight that had also undergone bilateral thoracotomies but had not breathed high concentrations of oxygen served as controls for these measurements.

Analytic methods. We centrifuged samples of blood and lymph and measured concentrations of protein in the supernatant fluids with a refractometer (American Optical Corp., Buffalo, NY) and confirmed these concentrations by the biuret method (16).

For the measurement of ethane and pentane, we transferred the gas in the bag to an evacuated 1-L flask, using Drierite to remove moisture in the gas sample. Then we warmed the flask to $40^{\circ} \mathrm{C}$ to minimize the condensation of pentane and transferred $200 \mathrm{~mL}$ of the gas to a second evacuated flask through a sample loop filled with activated alumina and cooled to $-130^{\circ} \mathrm{C}$ in a slush of ethanol and liquid nitrogen. We calculated the volume of gas transferred from the change in pressure monitored by a vacuum gauge. Then we analyzed the hydrocarbons trapped in the sample loop by gas chromatography using a Varian model 3700 gas chromatograph (Varian Associates, Inc., Palo Alto, CA) fitted with a 10 -foot stainless steel column packed with activated alumina. We used a six-way Carle valve (Carle Instruments, Inc., Anaheim, CA) to switch the carrier gas stream through the sample loop while immersing the loop in boiling water to facilitate elution of the trapped hydrocarbons. After $2 \mathrm{~min}$ at $50^{\circ} \mathrm{C}$, the program increased the oven temperature $250^{\circ} \mathrm{C}$ at $30^{\circ} \mathrm{C} / \mathrm{min}$, with a 10 -min hold. We used flame ionization to detect eluted hydrocarbons and quantitated them by comparing peak areas with standard curves obtained by analysis of known amounts of standards.

To test the system for recovery and analysis of hydrocarbons, we performed repeated experiments with test lungs filled with known amounts of hydrocarbons. This system gave complete recovery of methane, ethane, propane, butane, pentane, and hexane without contamination provided that: 1) meticulous care was taken to prevent room air leaks; 2) the flasks were scrupulously cleaned and dried in a vacuum oven before use; 3) the rate of sampling was sufficiently low; and 4) the length of tubing of the system was not excessive, i.e. the sample collection apparatus was located close to the mask and the transfer lines were warmed to prevent losses of the higher hydrocarbons to condensation.

For measurement of tissue antioxidants, we weighed and homogenized portions of frozen tissue using $10 \mathrm{~mL}$ of buffer $(0.1$ $\mathrm{M} \mathrm{KPO}_{4}, \mathrm{pH} 7.5$ ) per $\mathrm{g}$ of tissue. We measured GSH and GSSG in the homogenate, catalase in a 700 -g supernatant fraction, and SOD, glutathione peroxidase, and glutathione reductase in the 100000 -g supernatant by methods we have described previously (4). However, in our present report, we calculated the activities of glutathione peroxidase and reductase directly from the rate of change in A340 and the molar extinction coefficient of NADPH of $6.22 \times 10^{6} \mathrm{~cm}^{2}$ rather than by comparison with standard curves derived from enzymes purchased from commercial sources as was used previously (4). We measured protein and DNA contents of the three fractions as before (4) and calculated enzyme activities per mg of tissue, per $\mathrm{mg}$ of protein, and per mg of DNA. 
Statistical analysis. We used a one-way analysis of variance with the Student Newman-Keuls test to compare the daily measurements of ethane and pentane elimination. We compared the remainder of the physiologic measurements only on the first and last days in oxygen using a paired $t$ test and used the unpaired $t$ test and the Mann-Whitney $U$ test to compare the tissue measurements. We expressed all data in the text and tables as the mean \pm 1 SEM from the mean and accepted as significant those differences that were supported by a $p$ value $<0.05$.

\section{RESULTS}

After 48-96 $\mathrm{h}$ in oxygen, the lambs became lethargic and began to develop respiratory distress. From this time on, we observed the lambs continuously and euthanized them when their $\mathrm{P}_{2} \mathrm{CO}_{2}$ began to increase (Table 1). Five lambs were euthanized on $\mathrm{d} 4$ (after $72 \mathrm{~h}$ of breathing $>95 \%$ oxygen) and five lambs were euthanized on $\mathrm{d} 5$.

Aortic pressures and heart rates did not change between the first and last days of the experiment $(11.3 \pm 0.3$ versus $10.6 \pm$ $0.8 \mathrm{kPa}$ and $158 \pm 6$ versus $146 \pm 6$ beats/min, respectively). Pulmonary arterial and left atrial pressures also remained constant (Table 1).

Between the first and last days of oxygen breathing, the rate of lung lymph flow increased dramatically in each lamb such that by the last day, lymph flow had more than doubled (Table 2). In addition, the concentration of protein in lymph increased and the plasma protein concentration remained constant, so that the lymph to plasma protein ratio increased significantly.

Coincident with the increase in the rate of lung lymph flow, the lambs showed evidence for a deterioration in pulmonary function. Phasic swings in intrapleural pressure increased 3-fold (Table 1), $\mathrm{pH}$ and $\mathrm{P}_{\mathrm{a}} \mathrm{O}_{2}$ decreased, and $\mathrm{P}_{\mathrm{a}} \mathrm{CO}_{2}$ increased. At postmortem examination, the lungs appeared edematous and poorly aerated. Extravascular lung water content per g of dry, bloodless lung was significantly greater than that of control lambs $(5.83 \pm 0.37$ versus $4.50 \pm 0.25 \mathrm{~g} / \mathrm{g})$.

No increase in the rates of expiration of ethane or pentane were observed through $5 \mathrm{~d}$ of exposure to hyperoxia (Fig. 1).

The concentrations of GSH in the lungs of the oxygen toxic lambs were approximately half of those observed in control animals, whereas the tissue GSSG concentrations were approximately doubled (Table 3 ). As a result, the GSH/GSSG ratios were about $1 / 3$ of controls.

Further study of glutathione-dependent antioxidant defenses revealed an apparent decrease in activities of glutathione reductase in lung tissues in the hyperoxia-exposed lambs (Table 4). Because of the marked accumulation of water and plasma pro- teins in the interstitium and the changes that occur in relative cell populations in oxygen-induced lung injury, we also evaluated this apparent change in reductase activity per mg of tissue and per mg of protein and found the change to be significant statistically by unpaired $t$ test for all methods of expression (data not shown). Glutathione peroxidase activities were not different in the control and oxygen-toxic lambs (Table 4). Lung activities of SOD also were found to be significantly lower in the hyperoxic lambs than in the control animals (Table 4). This change was statistically significant regardless of the units used for expression of activity. In contrast, catalase activities were not different between the two groups of animals.

\section{DISCUSSION}

Previous work from our laboratory revealed a close correlation between alkane expiration and reactive oxygen-mediated tissue injury in vivo (9). Therefore, we sought to determine whether or not a similar relationship might exist between hyperoxic lung injury in newborn lambs and the production of ethane and pentane. In the lamb, oxygen-induced lung injury is manifest by a sudden increase in microvascular permeability to protein $(2$, 17). This injury typically occurs after $2-3 \mathrm{~d}$ of breathing $>95 \%$ oxygen and is highly predictable. It was our hypothesis that this abrupt loss of control of vascular permeability was the result of a collapse of the antioxidant defense mechanisms under the oxidant stress of continuous hyperoxic exposure and that a burst of peroxidative activity would coincide with the collapse. In our experiments, lung lymph flow increased and the protein concentration of lymph increased after $2-3 \mathrm{~d}$ of breathing $>95 \%$ oxygen. These findings are similar to those seen in other experiments $(2$, 17 ) in oxygen-toxic lambs and represent clear-cut evidence for injury to the microvascular bed of the lung. The increase in microvascular permeability was accompanied by an accumulation of fluid in the extravascular space of the lung as evidenced by the deterioration in gas exchange despite increases in respiratory effort and by the finding of pulmonary edema on postmortem examination. However, the onset of increased vascular permeability was not accompanied by increased expiration of ethane or pentane (Fig. 1).

Other investigators have reported increased rates of alkane excretion in response to hyperoxic lung injury. Morita et al. (18) reported a doubling in the rate of pentane excretion in adult humans after a 2 -h exposure to $100 \%$ oxygen, whereas Habib et al. (19) reported an acute increase in ethane expiration by adult rats exposed to $100 \%$ oxygen. On the other hand, Wispé et al. (20) found no significant increase in ethane or pentane expiration by newborn rabbits during a $3-d$ exposure to $>90 \%$ oxygen (20).

Table 1. Hemodynamic data and arterial blood gas tensions in lambs breathing $>95 \%$ oxygen*

\begin{tabular}{|c|c|c|c|c|c|c|c|c|c|}
\hline & \multirow{2}{*}{$\begin{array}{c}\text { Ppa } \\
(\mathrm{kPa})\end{array}$} & \multirow{2}{*}{$\begin{array}{c}\mathrm{Pla} \\
(\mathrm{kPa})\end{array}$} & \multirow[b]{2}{*}{$\mathrm{RR}$} & \multicolumn{2}{|c|}{$\mathrm{Ppl}(\mathrm{kPa})$} & \multirow[b]{2}{*}{ Hct } & \multirow[b]{2}{*}{$\mathrm{pH}$} & \multirow{2}{*}{$\begin{array}{l}\mathrm{P}_{\mathrm{a}} \mathrm{O}_{2} \\
(\mathrm{kPa})\end{array}$} & \multirow{2}{*}{$\begin{array}{c}\mathrm{PaCO}_{2} \\
(\mathrm{kPa})\end{array}$} \\
\hline & & & & Mean & Phasic & & & & \\
\hline $\begin{array}{l}\text { Day } 1 \\
(n=10)\end{array}$ & $1.9 \pm 0.1$ & $0.40 \pm 0.10$ & $49 \pm 6$ & $-0.27 \pm 0.06$ & $0.66 \pm 0.06$ & $27 \pm 1$ & $7.41 \pm 0.01$ & $53.6 \pm 1.3$ & $6.2 \pm 0.1$ \\
\hline $\begin{array}{l}\text { Day } 2 \\
(n=10)\end{array}$ & $2.0 \pm 0.1$ & $0.26 \pm 0.10$ & $37 \pm 3$ & $-0.27 \pm 0.06$ & $1.06 \pm 0.06$ & $28 \pm 1$ & $7.39 \pm 0.01$ & $52.0 \pm 1.7$ & $7.3 \pm 0.2$ \\
\hline $\begin{array}{l}\text { Day } 3 \\
(n=10)\end{array}$ & $2.0 \pm 0.1$ & $0.26 \pm 0.10$ & $32 \pm 2$ & $-0.27 \pm 0.06$ & $1.06 \pm 0.10$ & $28 \pm 1$ & $7.37 \pm 0.02$ & $54.5 \pm 1.7$ & $7.7 \pm 0.5$ \\
\hline $\begin{array}{l}\text { Day } 5 \\
(n=5)\end{array}$ & $1.7 \pm 0.1$ & $-0.10 \pm 0.10$ & $31 \pm 3$ & $-0.53 \pm 0.10$ & $2.53 \pm 0.10$ & $29 \pm 3$ & $7.12 \pm 0.07$ & $25.6 \pm 5.2$ & $13.7 \pm 1.6$ \\
\hline $\begin{array}{l}\text { Last day } \\
(n=10)\end{array}$ & $1.7 \pm 0.1$ & $0.40 \pm 0.10$ & $32 \pm 2 \dagger$ & $-0.40 \pm 0.06$ & $2.13 \pm 0.10 \dagger$ & $30 \pm 2$ & $7.13 \pm 0.05 \dagger$ & $25.3 \pm 4.1 \dagger$ & $13.4 \pm 1.2 \dagger$ \\
\hline
\end{tabular}

* Abbreviations: Ppa, mean pulmonary arterial pressure; Pla, mean left atrial pressure; RR, respiratory rate; Ppl, pleural pressure; Hct, hematocrit. For Ppl, both means and phasics (peak airway pressure-end expiratory pressure) are given. Data are presented as mean \pm SEM. Half of the lambs were killed on $\mathrm{d} 4$ and half on $\mathrm{d} 5$. Therefore, the data are compared between $\mathrm{d} 1$ and the day the lambs were killed (last day) using a paired $t$ test.

$\uparrow$ Denotes difference from $\mathrm{d} 1, p<0.05$. 
Table 2. Lung lymph flows and protein concentrations in 10 lambs on first and last days in $>95 \%$ oxygen*

\begin{tabular}{|c|c|c|c|c|}
\hline & \multirow{2}{*}{$\begin{array}{l}\text { Lymph flow } \\
\text { (mL/30 min) }\end{array}$} & \multicolumn{2}{|c|}{$\begin{array}{c}\text { Protein } \\
\text { concentration } \\
(\mathrm{g} / \mathrm{L})\end{array}$} & \multirow{2}{*}{$\begin{array}{c}\text { Lymph:plasma } \\
\text { protein ratio }\end{array}$} \\
\hline & & Lymph & Plasma & \\
\hline $\begin{array}{l}\text { Day } 1 \\
(n=10)\end{array}$ & $1.3 \pm 0.2$ & $37 \pm 2$ & $61 \pm 2$ & $0.61 \pm 0.02$ \\
\hline $\begin{array}{l}\text { Day } 2 \\
(n=10)\end{array}$ & $1.2 \pm 0.3$ & $39 \pm 2$ & $61 \pm 2$ & $0.62 \pm 0.02$ \\
\hline $\begin{array}{l}\text { Day } 3 \\
(n=10)\end{array}$ & $1.1 \pm 0.2$ & $37 \pm 2$ & $61 \pm 2$ & $0.61 \pm 0.01$ \\
\hline $\begin{array}{l}\text { Day } 4 \\
(n=10)\end{array}$ & $2.2 \pm 0.5$ & $41 \pm 2$ & $61 \pm 2$ & $0.68 \pm 0.02$ \\
\hline $\begin{array}{l}\text { Day } 5 \\
(n=5)\end{array}$ & $2.5 \pm 0.4$ & $44 \pm 2$ & $62 \pm 2$ & $0.71 \pm 0.04$ \\
\hline $\begin{array}{l}\text { Last day } \\
(n=10)\end{array}$ & $2.9 \pm 0.3 \dagger$ & $40 \pm 2 \dagger$ & $59 \pm 2$ & $0.69 \pm 0.02 \dagger$ \\
\hline
\end{tabular}

* Data are presented as mean \pm SEM. Half of the lambs were killed on $\mathrm{d} 4$ and half on $\mathrm{d} 5$. Therefore, the data are compared between $\mathrm{d} 1$ and the day the lambs were killed (last day) using a paired $t$ test.

$\uparrow$ Denotes difference from d $1, p<0.05$.

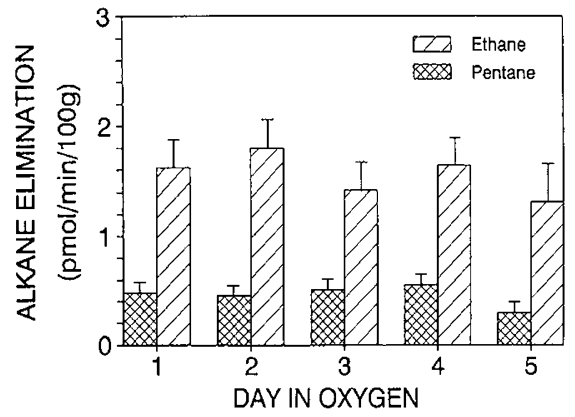

Fig. 1. The rates of excretion of ethane and pentane did not change as the lambs breathed $>95 \%$ oxygen continuously. There were a total of seven lambs on d 1-4 and five on d 5. Data are presented as mean \pm SEM and analyzed using analysis of variance.

We have no explanation for the differences in these studies. The rates of ethane and pentane expiration we observed in lambs in our study are comparable to the basal rates that we have observed in rats (9) and to the values obtained by Habib and Katz in rats (21) and guinea pigs (22) and by Wispe et al. in newborn rabbits and human infants (20). The experimental protocols used in the respective investigations differ in a number of ways, not the least of which is the species studied. Further, despite the superb sensitivity with which ethane and pentane expiration can be measured and the noninvasive methods by which these alkanes can be sampled, a number of factors other than the amount of lipid peroxidized can influence the amounts of ethane and pentane expired $(9,11,23,24)$.

The lack of an increase in expiration of ethane and pentane might suggest that lipid peroxidation is not significantly involved in the expression of oxygen toxicity in the lamb. However, it should be noted that ethane and pentane expiration may not reflect accurately the extent of lipid peroxidation, particularly because the yield of pentane obtained from the $\mathrm{Fe}_{2}{ }^{+}$-mediated decomposition of 15-hydroperoxyeicosatetraenoic acid in vitro is increased more than 100 -fold by removal of $\mathrm{O}_{2}$, relative to the yield of pentane obtained in oxygen-saturated media. This effect is thought to be the result of the efficient trapping of the 1-pentyl free radical by $\mathrm{O}_{2}$, with the subsequent formation of 1-pentanol (23). Preliminary studies have revealed small amounts of 1pentanol in lung tissue of hyperoxic lambs, but the extent to which ethanol, 1-pentanol, or other respective alcohols may provide useful markers of lipid peroxidation under hyperoxia or other situations requires further examination.
Increased production of GSSG is a very useful marker of cellular exposure to $\mathrm{H}_{2} \mathrm{O}_{2}$ or other hydroperoxide substrates for glutathione peroxidase $(9,25,26)$, although severe deficiency of dietary selenium has been shown to decrease the magnitude of this response (27). In agreement with the expectation that hyperoxic exposure should cause an oxidant stress, lung tissue concentrations of GSSG in the hyperoxia-exposed lambs were found to be about twice the mean concentrations observed in control animals (Table 3). The increase in lung GSSG concentrations and decrease in lung GSH concentrations and GSH/GSSG ratios that we observed are similar to those reported previously (4). However, the pathophysiologic relevance of these changes is not certain. In rat liver, much larger increases in production of GSSG can be induced without initiating observable damage $(9,10,26)$, and much larger decreases in GSH concentrations and GSH/ GSSG ratios can be produced without jeopardizing viability (28). The effects of GSH depletion on the ability of the lung to withstand an oxidant stress are not clear. Deneke et al. (29) found that rats fed a diet deficient in sulfur-containing amino acids were more susceptible to oxygen-induced lung injury. Furthermore, although lung GSH content increased with duration of oxygen exposure in rats fed a normal protein diet or one supplemented with cysteine, GSH content decreased during the hyperoxic exposure of rats fed a diet deficient in sulfur-containing amino acids. On the other hand, Coursin and Cihla (30) found that pretreatment of rats with buthionine sulfoximine a glutathione synthesis inhibitor, did not increase the susceptibility to the lethal effects of $>98 \%$ oxygen. It is possible that the differences between these studies might result from one or more lung cell types being extremely sensitive to shifts in the thiol/disulfide ratio or to the oxidant stress being preferentially localized to a specific cell type or subcellular compartment. Obviously, these effects would not be readily identified by whole tissue measurements. Kennedy et al. (31) have shown that the oxygen-induced increase in whole lung antioxidants is not readily explained by alveolar type II cell hypertrophy or by subcellular changes within the type II cells, but changes of this nature in other cell types are possible.

Table 3. Effect of hyperoxia on lung content of $G S H$ and $G S S G^{*}$

\begin{tabular}{|c|c|c|c|c|}
\hline & $n$ & $\begin{array}{c}\text { GSH } \\
(\mathrm{nmol} / \mathrm{mg} \mathrm{DNA})\end{array}$ & $\begin{array}{c}\text { GSSG } \\
(\mathrm{nmol} / \mathrm{mg} \mathrm{DNA})\end{array}$ & GSH/GSSG \\
\hline Control & 6 & $255 \pm 63$ & $2.68 \pm 0.42$ & $91.5 \pm 7.9$ \\
\hline Oxygen & 10 & $152 \pm 25$ & $4.97 \pm 0.85$ & $32.2 \pm 4.7$ \\
\hline$p$ & & $<0.05$ & $<0.02$ & $<0.001$ \\
\hline
\end{tabular}

* The measured mg of DNA per $g$ of tissue in the control and experimental groups were $5.22 \pm 0.07$ and $5.02 \pm 0.05$, respectively. The data are presented as mean \pm SEM. Because the variances were unequal, the tissue GSH and GSSG contents were compared using the MannWhitney $\mathrm{U}$ test. The GSH/GSSG ratio data were compared using an unpaired $t$ test.

Table 4. Effect of hyperoxia on lamb lung SOD, catalase, glutathione peroxidase, and glutathione reductase activities*

\begin{tabular}{ccccc}
\hline & SOD & Catalase & $\begin{array}{c}\text { Glutathione } \\
\text { peroxidase }\end{array}$ & $\begin{array}{c}\text { Glutathione } \\
\text { reductase }\end{array}$ \\
\hline Control & $4650 \pm 1250$ & $1290 \pm 220$ & $44.5 \pm 8.0$ & $4.78 \pm 1.25$ \\
Oxygen & $1360 \pm 530 \dagger$ & $1250 \pm 110$ & $33.4 \pm 5.1$ & $1.76 \pm 0.52 \dagger$ \\
\hline
\end{tabular}

* All data are expressed as mean \pm SEM (U/mg DNA). Per $g$ of tissue, an average of 34.8 and $39.9 \mathrm{mg}$ of protein and 0.674 and $0.568 \mathrm{mg}$ of DNA were obtained in the 700-g supernatants of control and hyperoxiaexposed lambs, respectively. In the 100000 -g supernatants, mean recoveries of 24.3 and $29.6 \mathrm{mg}$ of protein and 0.162 and $0.234 \mu \mathrm{g}$ of DNA were obtained per $g$ of tissue from the control and hyperoxic lambs, respectively.

$\dagger$ Denotes that the activity of the enzyme was significantly less than that found in the controls. 
The effects of hyperoxic exposure on the activities of glutathione peroxidase, glutathione reductase, SOD, and catalase in lung tissue were examined previously (4). Our present data are consistent with the previous data (4) in the lack of a difference in the activities of catalase or glutathione peroxidase, but differ in that the present data reveal significantly lower activities of glutathione reductase and SOD in the oxygen-exposed animals (Table 4). The biochemical determinations for the two studies were conducted in the same laboratory by the same investigator using the same methods, so the apparent difference in the results is surprising. In the previous study, the mean value for glutathione reductase activity was $24 \%$ lower in the hyperoxic animals than in the controls. Although this difference was not statistically significant, the trend was very similar to that seen in this report. The effects of hyperoxic exposure on the lung SOD activities are, however, clearly different in the two studies and the origin of this difference is not understood at this time.

The possibility that the decreases in glutathione reductase and SOD activities are secondary effects of degenerative changes in dead cells must be considered, but the absence of comparable decreases in glutathione peroxidase or catalase activities does not support that hypothesis. The enzyme activities were evaluated per $\mathrm{mg}$ of tissue, per $\mathrm{mg}$ of protein, and per $\mathrm{mg}$ of DNA in an attempt to minimize the influence of changes in tissue content of water and extracellular protein as well as changes in relative cell populations, but the persistence of the statistical differences in each unit of expression does not support this possibility. It is notable that unlike the failure of the glutathione synthesis inhibitor buthionine sulfoximine to alter the lethality of hyperoxic exposure in rats, Kerher and Paraidathathu (6) did observe a significant enhancement of the toxicity of $85 \% \quad \mathrm{O}_{2}$ to mice pretreated with 1,3-bis(2-chloroethyl)-1-nitrosourea, which is a relatively selective inhibitor of glutathione reductase.

Our present data (Table 4) and the data in the previous study by Hazinski et al. (4) also differ somewhat in the absolute activities of glutathione peroxidase, glutathione reductase, and SOD. A significant portion of the apparent differences in glutathione peroxidase and glutathione reductase activities arises from the calculation of the present data directly from the molar extinction coefficient of NADPH, whereas in the previous study, standard curves based on dilutions of enzymes purchased from a commercial supplier were used. However, the SOD activities in the control animals in the present siudy are about 8 -fold higher than those reported in the previous study. The extent to which this difference is attributable to biologic variability in the lambs is not known at this time.

The absence of an increase in the expiration of ethane or pentane in the hyperoxic lambs does not prove that lipid peroxidation is not a critical event in the initiation and progression of lung injury, but other analytical approaches need to be examined. We do not regard the observed changes in thiol/disulfide status as probable mechanisms of injury, but other investigators may wish to interpret the available evidence differently. The hyperoxia-induced changes in enzyme activities may prove to be mechanistically informative and possibly critical to the pathogenetic mechanisms, but this question will require additional investigation.

\section{REFERENCES}

1. Avery ME, Tooley WH, Keller J, Hurd SS, Bryan H, Cotton R, Epstein MD, Fitzhardinge P, Hansen C, Hansen TN, Hodson WA, James LS, Kitterman JA, Nielsen HC, Poirer TA, Truog WE, Wung JT 1987 Is chronic lung disease in low-birth weight infants preventable? A survey of eight centers. Pediatrics 79:26-36

2. Bressack MA, McMillan DD, Bland RD 1979 Pulmonary oxygen toxicity: increased microvascular permeability to protein in unanesthetised lambs. Lymphology 12:133-139

3. Frank L, Bucher JR, Roberts RJ 1978 Oxygen toxicity in neonatal and adult animals of various species. J Appl Physiol 45:699-704

4. Hazinski TA, Kennedy KA, France ML, Hansen TN 1988 Pulmonary $\mathrm{O}_{2}$ toxicity in lambs: physiological and biochemical effects of endotoxin infusion. J Appl Physiol 65:1579-1585

5. White CW, Mimmack RF, Repine JE 1986 Accumulation of lung tissue oxidized glutathione (GSSG) as a marker of oxidant induced lung injury. Chest 89:111S-113S

6. Kehrer JP, Paraidathathu T 1984 Enhanced oxygen toxicity following treatment with 1,3-Bis(2-chloroethyl)-1-nitrosurea. Fundam Appl Toxicol 4:760767

7. Suttorp N, Simon LM 1986 Importance of the glutathione redox cycle for the resistance of lung epithelial cells against a polymorphonuclear leukocytemediated oxidant attack. Biochem Pharmacol 35:2268-2270

8. Tsan M, Danis EH, Del Vecchio PJ, Rosano CL 1985 Enhancement of intracellular glutathione protects endothelial cells against oxidant damage. Biochem Biophys Res Commun 127:270-276

9. Smith CV 1987 Evidence for the participation of lipid peroxidation and iron in diquat-induced hepatic necrosis in vivo. Mol Pharmacol 32:417-422

10. Smith CV 1987 Effect of BCNU pretreatment on diquat-induced oxidant stress and hepatotoxicity. Biochem Biophys Res Commun 144:415-421

11. Smith CV, Anderson RE 1987 Methods for determination of lipid peroxidation in biological samples. Free Radic Biol Med 3:341-344

12. Bland RD, McMillan DD 1977 Lung fluid dynamics in awake newborn lambs. J Clin Invest 60:1107-1115

13. Staub NC, Bland RD, Brigham KL, Demling AJ, Erdmann WC, Woolverton WC 1975 Preparation of chronic lung lymph fistulas in sheep. J Surg Res 19:315-320

14. Erdmann WC, Vaughan TR, Brigham KL, Woolverton WC, Staub NC 1975 Effect of increased vascular pressure on lung fluid balance in unanesthetized sheep. Circ Res 37:271-284

15. Pearce ML, Yamashita J, Beazell J 1965 Measurement of pulmonary edema. Circ Res 16:482-488

16. Gornall AB, Bardawill CJ, David MM 1949 Determination of serum proteins by means of the Biuret reaction. J Biol Chem 177:751-766

17. Hansen TN, Hazinski TA, Bland RD 1982 Vitamin E does not prevent oxygeninduced lung injury in newborn lambs. Pediatr Res 15:583-587

18. Morita S, Snider MT, Inada Y 1986 Increased $n$-pentane excretion in humans: a consequence of pulmonary oxygen exposure. Anesthesiology 64:730-733

19. Habib MP, Eskelson C, Katz MA 1988 Ethane production rate in rats exposed to high oxygen concentration. Am Rev Respir Dis 137:341-344

20. Wispé JR, Bell EF, Roberts RJ 1985 Assessment of lipid peroxidation in newborn infants and rabbits by measurement of expired ethane and pentane: influence of parenteral lipid infusion. Pediatr Res 19:374-379

21. Habib MP, Katz MA 1989 Source of ethane in expirate of rats ventilated with 100\% oxygen. J Appl Physiol 66:1268-1272

22. Habib MP, Katz MA 1989 Ethane production rates and minute ventilation. J Appl Physiol 66:1264-1267

23. Smith CV, Reilly MH 1989 Formation of pentane versus 1-pentanol in the ferrous sulfate-initiated decomposition of 15-hydroperoxyeicosatetraenoic acid in hypoxic and hyperoxic conditions. Biochem Pharmacol 38:13621364

24. Smith CV, Hughes H, Lauterburg BH, Mitchell JR 1983 Chemical nature of reactive metabolites determines their biological interactions with glutathione. In: Larsson A, Orrenius S, Holmgren A, Mannervik B (eds) Functions of Glutathione: Biochemical, Physiological and Toxicological Aspects, Raven Press, New York, pp 125-138

25. Adams Jr JD, Lauterburg BJ, Mitchell JR 1983 Plasma glutathione and glutathione disulfide in the rat: regulation and response to oxidative stress. J Pharmacol Exp Ther 227:749-754

26. Lauterburg BH, Smith CV, Hughes H, Mitchell JR 1984 Biliary excretion of glutathione and glutathione disulfide in the rat: regulation and response to oxidative stress. J Clin Invest 73:124-133

27. Jenkinson SG, Spence TH, Lawrence RA, Hill KE, Duncan CA, Johnson KH 1987 Rat lung glutathione release: response to oxidative stress and selenium deficiency. J Appl Physiol 62:55-60

28. Smith CV, Jaeschke H 1989 Effect of acetaminophen on hepatic content and biliary efflux of glutathione disulfide in mice. Chem Biol Interact 70:241248

29. Deneke SM, Gershoff SN, Fanburg BL 1983 Potentiation of oxygen toxicity in rats by dietary protein or amino acid deficiency. J Appl Physiol 54:147151

30. Coursin DB, Cihla HP 1988 The pulmonary effects of buthionine sulfoximine treatment and glutathione depletion in rats. Am Rev Respir Dis 138:14711479

31. Kennedy KA, Crouch IS, Warshaw JB 1989 Effect of hyperoxia on antioxidants in neonatal rat type II cells in vitro and in vivo. Pediatr Res 26:400403 